\title{
IS HOBBES REALLY AN ANTIREALIST ABOUT ACCIDENTS?
}

\author{
SAHAR JOAKIM \\ Saint Louis University \\ C. P. RAGLAND \\ Saint Louis University
}

Original scientific article - Received: 04/08/2017 Accepted: 25/11/2018

\begin{abstract}
In Metaphysical Themes, Robert Pasnau interprets Thomas Hobbes as an anti-realist about all accidents in general. In opposition to Pasnau, we argue that Hobbes is a realist about some accidents (e.g., motion and magnitude). Section one presents Pasnau's position on Hobbes; namely, that Hobbes is an unqualified antirealist of the eliminativist sort. Section two offers reasons to reject Pasnau's interpretation. Hobbes explains that magnitude is mindindependent, and he offers an account of perception in terms of motion (understood as a mind-independent feature of body). Therefore, it seems incorrect to call Hobbes an anti-realist about all accidents. Section three considers Pasnau's hypothetical response: he might claim that for Hobbes, motion reduces to body and does not exist in its own right. Section four notes that reductionism about all accidents does not entail anti-realism about all accidents. Even granting Pasnau's anticipated response, his anti-realist reading does not follow. Contra Pasnau, Hobbes is best understood as claiming that motion and magnitude exist mind-independently.
\end{abstract}

Keywords: Hobbes, Pasnau, antirealism about accidents, body, motion 


\section{Pasnau's Position on Hobbes}

Thomas Hobbes says in one place: "Whatsoever accidents or qualities our senses make us think there be in the world, they are not there, but are seemings and apparitions only" (Hobbes 1640, I. 2.10). What does this remark mean? One natural interpretation is the following: the mindindependent world contains no accidents (as distinct from substances); accidents are only 'seemings and apparitions' in our minds.

Robert Pasnau, for example, adopts this interpretation of Hobbes. Pasnau (2011, section 22.5) argues that for Hobbes, accidents are either: (a) nothing more real than bodies variously situated that move, or (b) nothing more real than our sensory experiences mistakenly projected onto bodies.

According to Pasnau, Hobbes denies any real existence to secondary qualities such as color and smell and also denies real existence even to kinetic-geometric primary qualities such as motion and size. Pasnau paints Hobbes as an unqualified anti-realist about all accidents. ${ }^{1}$ Pasnau (2011, 649) explains,

Hobbes categorically rejects the notion of accidents, and with it rejects the substance-accident distinction. According to Hobbes's ontology, there are only substances, some larger and some smaller. Nothing else has a place in his ontology: no forms, no accidents, no modes, and - in particular-no essences... When we use such metaphysical language to talk about bodies, we are speaking of nothing more than "the mode of conceiving a body". (De corpore 8.2; emphasis added)

Hobbes says that an accident is "the mode of conceiving a body", and that accidents "are seemings and apparitions only" (Hobbes 1640, I. 2.10), and Pasnau takes him seriously. According to Pasnau, Hobbes proposes "the thoroughgoing elimination of accidents in favor of an ontology of substances alone, conceived in various ways". ${ }^{2}$ This "thoroughgoing elimination" amounts to moving accidents into the mind and rejecting their mind-independent existence. If accidents are mere conceptions of substance, then all accidents are mind-dependent.

Let's reflect further on the accident of color. Hobbes says that "the subject wherein colour and image are inherent is not the object or thing seen ...

\footnotetext{
${ }^{1}$ For Pasnau on Hobbes as an anti-realist regarding sensible qualities, see mainly 22.5 of Metaphysical Themes.

${ }^{2}$ This reference is in Pasnau $(2011,170$; but see also section 7.1).
} 
but the sentient" (Hobbes 1640, I. 2. 4). Pasnau correctly glosses this as: "... the thing we perceive - the very image, and the very color-is not something out in the world, but something in the mind" (Pasnau 2011, 516; emphasis added). When I see a green object, the green I see is not really in the world external to my mind; instead, the perceived color exists only in my mind.

Pasnau's interpretation becomes controversial when he claims that Hobbes denies mind-independent existence not only for secondary qualities like color but also for primary qualities such as motion. That is, Pasnau attributes an unqualified anti-realist position to Hobbes (see Pasnau 2011, 516). An unqualified anti-realist denies that any accident has its existence independent of minds and claims that all accidents are mind-dependent. Pasnau claims that for Hobbes, what answers to my idea of a substance is somewhere in the world, but what answers to my idea of any one of its accidents is only in my mind.

According to Pasnau, Hobbes categorically rejects the mind-independent existence of everything except substance. And by substance, Hobbes means body: "What really exist, for Hobbes, are permanent bodies" (Pasnau 2011, 713), so that the only thing in Hobbes's ontology is body. As Hobbes says: "The world (. . . the universe... the whole mass of all things that are) is corporeal - that is to say, body... also every part of body is likewise body" (bold emphasis added). ${ }^{3}$ For Pasnau's Hobbes, only one thing has mind-independent existence: body. ${ }^{4}$ Or in Latin: corpus. Anyone who accepts only body in their ontology is called a corpuscularian. Pasnau paints Hobbes as a "thoroughgoing corpuscularian" (Pasnau 2011, $11)$.

If Pasnau is right, then according to Hobbes everything that appears to exist (colors, motion, et cetera) is nothing but an appearance of body, and body is the only thing that really exists externally to one's mind. Therefore, claims about colors or motion cannot be made true by the mindindependent world alone, for these claims are in part about ideas or phantasms of the mind. However, we hope to show in the next section that this interpretation of Hobbes is a mistake.

\footnotetext{
${ }^{3}$ Hobbes, "Of Darkness from Vain Philosophy: errors concerning abstract essences". This is chapter XLVI of his Leviathan.

${ }^{4}$ One could be a realist about accidents, and either think that there are real accidents in the world that produce color experiences or that colors are merely features of experience; one could also be an antirealist about accidents and still think that colors are in the world as simply particles in motion (Thanks to an anonymous referee for pointing out this complexity). But Pasnau says that Hobbes is an unqualified anti-realist committed to denying mind-independent existence to both color and motion.
} 


\section{Objection to Pasnau's Position}

In this section, we object to Pasnau's interpretation of Hobbes as unqualified anti-realist about all accidents. To be clear, we agree with Pasnau that Hobbes is some sort of anti-realist about some accidents. We disagree with Pasnau, however, when he interprets Hobbes's anti-realism as extending to all accidents without qualification. We argue that contrary to Pasnau's reading, Hobbes is a realist about extension (or magnitude) and motion/rest.

The key text for understanding Hobbes' position on accidents is De Corpore (Concerning Body), the first section of his Elements of Philosophy. ${ }^{5}$ In De Corpore part II, entitled "The First Grounds of Philosophy", Hobbes defines place (space) and time. He asks his readers to imagine that everything in the world is annihilated except for one man. This person, Hobbes claims, would retain memories or ideas of sounds, colors, magnitudes, motions, and so forth. These memories,

though they be nothing but ideas and phantasms, happening internally to him that imagineth; yet they will appear as if they were external, and not at all depending upon any power of the mind. (DC II.7.1; EW I, 92)

Hobbes goes on to define space as "the Phantasm of a Thing existing without the Mind simply; that is to say, that Phantasm, in which we consider no other Accident, but only that it appears without us", and time as "a Phantasm of . . . Motion, namely an Idea of ... Body passing out of one Space into another by continual succession" (DC II.7.2; EW I, 94). For Hobbes, space and time are imaginary or mind-dependent, and yet possess the specious appearance of mind-independence. It is therefore natural to wonder whether spatio-temporal qualities (e.g., magnitude or motion) are also fundamentally mind-dependent according to Hobbes. Pasnau is not alone in supposing that they are. ${ }^{6}$

However, careful attention to Hobbes' subsequent discussion reveals that he is no proto-Kantian. Hobbes opens Chapter VIII, "Of Body and Accident", by asking readers to "suppose some one of those things [previously annihilated] to be placed again in the world, or created anew" (DC II.8.1; EW I, 102). Whereas in the initial stage of Hobbes' thought experiment, only the sole perceiver's mind and its ideas existed, now a mind-independent body is reintroduced. This new body will fill or be co-

\footnotetext{
${ }^{5}$ References to De Corpore are by part, chapter, and section number, followed by the volume and page number from Hobbes' English Works (EW).

${ }^{6}$ For another anti-realist interpretation, see Herbert (1987).
} 
extended with "some part of space above mentioned", but also will "have no dependence upon our thought". Hobbes continues:

And this is that which, for the extension of it, we commonly call body; and because it depends not upon our thought, we say is $a$ thing subsisting of itself; as also existing, because without us; and lastly, it is called the subject, because it is so placed in and subjected to imaginary space, that it may be understood by reason, as well as perceived by sense. The definition, therefore, of body may be this, a body is that which having no dependance upon our thought, is coincident or coextended with some part of space. (DC II.8.1; EW I, 102; emphasis added)

Four times in this passage, Hobbes indicates that bodies themselves are mind-independent, despite being placed in imaginary space whenever we perceive them. While the first stage of his thought experiment contemplated a sort of idealist picture, at this new stage, Hobbes makes clear that he is a realist about bodies. But what about accidents of bodies like magnitude and motion? Are they mind-independent like bodies themselves, or mind-dependent like space and time?

Hobbes seems reluctant to offer a definition of "accident". He says, "what an accident is, cannot so easily be explained by any definition, as by examples", and cites extension, motion and rest as paradigmatic attributes (DC II.8.2; EW I, 102). He insists that to ask, "what is an accident?" is "an enquiry after that which we know already ... For who does not always and in the same manner understand him that says any thing is extended, or moved, or not moved?" (DC II.8.2; EW I, 102-103) But because the lure of an explicit definition drives "most men" to mistakenly conceive of an accident as "something, namely some part of a natural thing", Hobbes corrects them with the following definition:

To satisfy these men, as well as may be, they answer best that define an accident to be the manner by which any body is conceived; which is all one as if they should say, an accident is that faculty of any body, by which it works in us a conception of itself. (DC II.8.2; EW I, 103; emphasis added)

The first part of this definition is the mantra of Pasnau's anti-realist interpretation. And since Hobbes has just been talking extension, motion, and rest, it is plausible to suppose that he takes these primary qualities to be ways in which a body is conceived. But notice: Hobbes immediately restates his definition in order to clarify it. An attribute is "the manner by which a body is conceived" or a "way of conceiving a body" in the sense that it is the cause of that conception. An accident is a faculty of a body 
by which it causes an idea of itself in an observer. This restatement is exceptionally good evidence that for Hobbes all accidents are not minddependent.

To explain why, we note that Hobbes continues the emphasis on causation in the very next lines as he comments on the definition of "accident" he has just offered:

Which definition, though it be not an answer to the question propounded, yet it is an answer to that question which should have been propounded, namely, whence does it happen that one part of any Body appears here, another there? For this is well answered thus: it happens from the extension of that body. Or, how comes it to pass that the whole body, by succession, is seen now here, now there? and the answer will be, by reason of its motion. Or lastly, whence is it that any body possesseth the same space for sometime? and the answer will be, because it is not moved. (DCII.8.2;EW I, 103; emphasis added)

A body's extension, motion and rest causally explain various features of that body's appearance. Hobbes is explicit that one of these causesextension - is just as mind-independent as the body to which it belongs. He says:

The extension of a body, is the same thing with the magnitude of it, or that which some call real space. But this magnitude does not depend upon our cogitation, as imaginary space doth; for this is an effect of our imagination, but magnitude is the cause of it; this is an accident of the mind, that of a Body existing out of the Mind. (DC II.8.4; EW I, 105; emphasis added)

In addition to the mind-dependent imaginary space, there is real space (i.e., true extension or magnitude), and only this latter mind-independent quality serves as a cause. Perhaps because of this passage, Pasnau admits that Hobbes takes body "to include (or perhaps consist of) magnitude and extension..." (Pasnau 2011, 32). But notice, Hobbes here says not that true extension is body, but that it is an accident of body.

While less explicit, Hobbes' language about motion in De Corpore also strongly suggests that it, too, is mind-independent. First, consider this list of reasons that Hobbes gives to prove the distinction between real and imaginary space:

... place is nothing out of the Mind, nor magnitude any thing within it ... place is feigned extension, but magnitude true extension; and a placed body is not extension, but 
a thing extended. Besides, place is immovable ... (DC II.8.5; EW I, 105; emphasis added)

Notice that Hobbes here speaks metaphysically, contrasting minddependent and mind-independent entities ("place" and "magnitude"). $\mathrm{He}$ then clearly intends to contrast immovable imaginary place with movable real bodies. In this context, he seems to suggest that the motion of bodies is just as real or mind-independent as the bodies themselves.

This mind-independence of motion is reinforced by Hobbes' reduction of causal power to motion. He says:

... the efficient cause of all motion and mutation consists in the motion of the agent, or agents; and ... the power of the agent is the same thing with the efficient cause. From whence it may be understood, that all active power consists in motion also; and that power is not a certain accident which differs from all acts, but is indeed an act, namely motion, which is therefore called power, because another act shall be produced by it afterwards. (DC II.10.6; EW I, 131)

Hobbes suggests that a mind-independent accident is "that faculty of any body, by which it works in us a conception of itself" (DC II.8.2; EW I, 103; emphasis added). If motion is causal power, and causal power is mindindependent, then motion is also mind-independent.

The mind-independent reality of both magnitude and motion/rest appears explicitly in Hobbes' account of perception. Hobbes says:

The cause of sense, is the external body, or object, which presseth the organ proper to each sense ... which pressure, by the mediation of nerves, and other strings and membranes of the body, continued inwards to the brain and heart, causeth there a resistance, or counter-pressure, or endeavor of the heart to deliver itself, which endeavor, because outward, seemeth to be some matter without. And this seeming, or, fancy, is that which men call sense ... (Hobbes 1651, I. 1; emphasis added)

A body's ability "to press itself onto our sense organ" is a feature of that body. Since pressure involves motion, Hobbes is telling us that an outward motion gives rise to our inward sensations of external objects. Hobbes continues with a discussion of what John Locke later called secondary qualities: 
And this seeming or fancy is that which men call sense, and consists, as to the eye, in a light or colour figured; to the ear, in a sound; to the nostril, in an odor; to the tongue and palate, in a savor; and to the rest of the body, in heat, cold, hardness, softness, and such other qualities as we discern by feeling. All which qualities called sensible are in the object that causes them but so many several motions of the matter by which it presses our organs diversely. Neither in us that are pressed are they any thing else but diverse motions (for motion produces nothing but motion). (Hobbes 1651, I. 1; emphasis added)

Notice: Hobbes here says that these secondary qualities are "in the object that causes them" as "several motions of the matter" (likewise, insofar as they are in the human mind, they are ultimately reducible to motion). Motion, it seems, is really in the object, apart from our perception, and thus can serve to explain that perception.

Two final passages confirm this interpretation. Hobbes says: "those things which the learned call the accidents of bodies are indeed nothing else but diversity of fancy, and are inherent in the sentient and not in the objects, except motion and quantity". ${ }^{7}$ What comes before the "except" seems to express Pasnau's interpretation of Hobbes. But then there is the limitation of the "except", which works against an unqualified antirealist reading. Motion, quantity, and magnitude are mind-independent objects, not sentient objects. As Hobbes himself says explicitly: The things that really are in the world without us are those motions by which these seemings [of perception] are caused" (Hobbes 1640, I. 2.10; emphasis added).

To sum up, we have displayed textual evidence demonstrating that for Hobbes, bodies are mind-independent, and that magnitude (extension) and motion/rest are mind-independent accidents or qualities of those bodies. In light of this evidence, we find ourselves in agreement with Slowik (2014): "despite [Hobbes'] hinting towards phenomenalism as regards bodily accidents (i.e., as they pertain to our cognitive faculties) ... the central importance of magnitude and motion in Hobbes' scheme would seem to undermine this more radical line of interpretation" (68).

Motion plays a key role in Hobbes' theory of perception in particular and causation in general. Frithiof Brandt says, "rather than being termed a metaphysical materialist, Hobbes should be called a motionalist, if we may

\footnotetext{
${ }^{7}$ Pasnau 2011, page 117, footnote 2 references Hobbes' Seven Philosophical Problems, VII. 28.
} 
be permitted to coin such a word" (Brandt 1928, 379). Leijenhorst provides a way to reconcile this motionalism with Hobbes' occasional remarks that an accident is just a "mode of conceiving a body". ${ }^{8}$ According to Leijenhorst, Hobbes's has two different conceptions of "accident". In the strict metaphysical sense, "an accident is not an objective mode of a body, but our subjective mode of conceiving body" (Leijenhorst 2001, 156; emphasis added). However, Hobbes is also committed to a realistic conception of accidents like magnitude and motion, and believes that "the phenomenalist accidents are the fruits of realist accidents" (Leijenhorst 2001, 157; emphasis added). ${ }^{9}$ Leijenhorst is correct: Hobbes is not the unqualified eliminativist that Pasnau depicts because primary qualities like magnitude and motion/rest are not equal in their standing with secondary qualities like color, taste, etc. Contra Pasnau, Hobbes is not the radical epitome of the unqualified rejection of all accidents.

Before considering how Pasnau might defend his position against our criticisms, we should note a possible textual objection to our interpretation. ${ }^{10}$ When Hobbes takes up the question of how accidents are "in" their subjects, he lists the following attributes as all on par with each other: "to be at rest, to be moved, colour, hardness" (DC II.8.3; EW I, 104). $\mathrm{He}$ goes on to insist that "colour, heat, odour . . . and the like" are in their subjects "in the same manner that extension, motion, rest, or figure are in the same", for he insists that "as magnitude, or rest, or motion, is in that which is great, or which resteth, or which is moved... so also, it is to be understood, that every other accident is in its subject" (emphasis added). These lines seem to challenge the distinction that we (and Leijenhorst) have drawn between phenomenal/subjective accidents and real/objective ones. If motion and color, for example, are both in a thing in the same way, then how can one be mind-dependent and the other mind-independent?

This objection fails because Hobbes' remarks in the relevant passage are not only consistent with our reading, but also confirm it. Hobbes' claim that all attributes are "in" their subject in the same manner is consistent with drawing distinctions among different kinds of attributes. For example, immediately after he says that "as magnitude... is in that which is great... so also... every other accident is in its subject", Hobbes himself distinguishes between essential and accidental attributes:

\footnotetext{
${ }^{8}$ Pasnau $(2011,117)$ references Hobbes's De Corpore 8.3.

${ }^{9}$ Pasnau (2011) explicitly rejects Leijenhorst's interpretation of Hobbes.

${ }^{10}$ Thanks to an anonymous referee for EuJAP for bringing this possible objection to our attention.
} 
... there are certain accidents which can never perish except the body perish also; for no body can be conceived to be without extension, or without figure. All other accidents... as to be at rest, to be moved, colour, hardness, and the like, do perish continually... [and yet] the body never perisheth. (DC II.8.3; EW I, 104)

Essential and non-essential properties are distinct from one another in an important sense even though they are both "in" bodies in the same way. Similarly, it is legitimate to distinguish between subjective phenomenal properties like color and objective properties like motion even though bodies "have" them in the same way.

Such a distinction is not only permitted by the passage in question but is indeed implied by its ending. Hobbes says:

... as for the opinion that some may have, that all other accidents are not in the bodies in the same manner that extension, motion, rest, or figure are in the same; for example, that colour, heat, odour, virtue, vice, and the like are otherwise in them, and, as they say, inherent; I desire they would suspend their judgment for the present, and expect a little, till it be found out by ratiocination, whether these very accidents are not also certain motions either of the mind of the perceiver, or of the bodies themselves which are perceived ... (DC II.8.3; EW I, 104-105; emphasis added).

This passage suggests the position that Hobbes affirms explicitly at Leviathan, I. 1, and which we quoted above in laying out our argument (see the block quote just before footnote 7): namely, that secondary or phenomenal qualities like color are both in the mind that perceives them and in the thing perceived. They are motions in the mind of the perceiver caused by motions in the perceived external object. Insofar as it is "in" the external object, color is reducible to the motion in the object that causes the subjective perception in the mind. Color and motion are both "in" the object in the same way because, ultimately, color in the object just is motion - a mind-independent attribute of the body.

\section{Pasnau's Anticipated Response}

In response to the evidence we have presented, Pasnau could attempt to maintain his position by noting that Hobbes is a reductionist about motion. Reducing motion to body itself, he might insist, amounts to anti-realism about accidents_-including magnitude and motion. 
One kind of anti-realism about accidents, Pasnau tells us, is motivated by a reductive account of reality (Pasnau 2011, 499). What is real, for Pasnau's Hobbes, is only body; and, everything that appears to exist is ultimately reducible to body itself. Pasnau attributes this form of antirealism about accidents to Hobbes, a position he calls "eliminativism". ${ }^{11}$ Moreover, Pasnau attributes a "deflationist" position to Hobbes. In his opening statement on deflationary accounts, Pasnau says:

I use the term 'deflationary' to cover a broad range of views on which forms are somehow less than full-fledged beings in their own right, which is to say that they do not exist in the same sense that substances exist. The most extreme sort of deflationist account, which we might call eliminativism, is the view that there simply are no such things as accidental forms. This strategy has its explicit defenders in the seventeenth century. We have already seen Hobbes, for instance, endorse this sort of view, with his remark that an accident is just "the mode of conceiving a body." (Pasnau 2011, 181 ; emphasis added)

Here, Pasnau is claiming that for an eliminativist, there are "no such things" as accidents. Pasnau does not add that for an eliminativist like Hobbes there are no such things as accidents in the external world, but this must be what he means. For he goes on to say that Hobbes's form of eliminativism makes accidents "modes of conceiving". If accidents are modes of conceiving, then accidents are something in the mind. So, Pasnau must really mean that eliminativists hold that there are no accidents external to the mind. Pasnau says:

So what exactly is an accident for Hobbes, if not one body's inhering in another? He defines it as "the mode of conceiving a body." With this, Hobbes is not just making the commonplace switch from talk of accidents to talk of modes, but further giving the notion of mode a subjective character, so that what counts as a mode depends entirely on how we conceive of a thing... accidents are no longer something in bodies distinct from the substance... to grasp a body's accidents just is to grasp something about the body itself. (Pasnau 2011, 117; emphasis added)

According to Pasnau's interpretation of Hobbes, accidents are distinct from bodies only in our minds; in reality, they are reducible to or identical with

\footnotetext{
${ }^{11}$ Pasnau, Metaphysical Themes. See sections 7.1. and 10.2, and see also page 261.
} 
bodies themselves. To grasp some feature of a body is just to grasp the body itself.

Thinking of motion as activity, Pasnau may argue that body exists externally to one's mind, and so does motion, but the motion (insofar as it is in the external world) is nothing over and above the body itself; rather it just is the body. The word "motion" may also refer to a mode of thought (i.e., a "fancy") that may be distinct in thought from the idea of body, but that is not relevant. Pasnau's point may be that when Hobbes considers motion not as a conception in the mind, but as something mindindependent, he no longer takes it to be distinct from body. For Pasnau's Hobbes, the substance/accident distinction applies only when human conceptualizing is in play. In the world alone, there is no such distinction: accidents collapse into their substances. In particular, motion is body existing first in one place, and then another.

According to Pasnau's interpretation of Hobbes's reductive project, in the mind-independent world no accident exists distinct from or in addition to bodies. Since Pasnau maintains that Hobbes is a reductionist about all accidents, he might take himself to have defended his claim that Hobbes is an anti-realist about all accidents. For on the reductionist view, accidentsunderstood as distinct from the bodies that possess them - exist only in our thought, not in the mind-independent world.

\section{Reply to Pasnau}

We maintain our original claim that Pasnau is incorrect to call Hobbes an unqualified anti-realist. Pasnau may be correct to call Hobbes a qualified anti-realist, denying the mind-independent existence of some (perhaps most) accidents. However, because Hobbes is not anti-realist about magnitude and motion, he is not an unqualified anti-realist about accidents. In the last section, we speculated that Pasnau might try to preserve his reading by suggesting that Hobbes is a reductionist about all accidents, including magnitude and motion. Here, we will first present evidence suggesting that Hobbes does not reduce magnitude and motion to body, and then we will argue that even if he does, such reduction does not amount to anti-realism.

The reductionism under consideration is the view that a body's magnitude and motion are in reality identical to the body itself. But in De Corpore when Hobbes first gives examples of accidents, he does not seem to identify them with body: 
Let us imagine, therefore, that a body fills any space, or is coextended with it; that coextension is not the coextended body: and, in like manner, let us imagine that the same body is removed out of its place; that removing is not the removed body: or let us think the same not removed; that not removing or rest is not the resting body. What then are these things? They are accidents of that body.(DCII.8.1;EWI, 102; emphasis added)

Extension, Hobbes says, is not the extended body, nor rest the resting body. Rather than identifying the body with its accidents, he is stressing their distinctness. Perceptive readers might note the opening appeal to imagination and wonder whether this distinction is a distinction in reality for Hobbes, or only a distinction in the mind. However, this passage occurs at the point in the De Corpore thought experiment where Hobbes has just reintroduced mind-independent bodies into the world, and is describing the attributes of such bodies. Therefore, he seems to be suggesting that accidents like motion and magnitude are in reality not identical with their bodies.

But we need not rest our entire response to Pasnau on this textual evidence. For even if Hobbes does reduce motion and magnitude to the moving body, it would not follow that he is an anti-realist about these accidents. Pasnau cannot, therefore, defend his unqualified anti-realist interpretation of Hobbes by defending his reductionist interpretation of Hobbes. Holding a reductionist position on all accidents does not entail an anti-realist position on all accidents.

There is a difference between reductionism and anti-realism. For example, to reduce motion to body is just to say that there is no such thing as motion distinct from or in addition to body. This is the sort of claim Pasnau attributes to Hobbes when he says that Hobbes is a reductionist about accidents. On the other hand, anti-realism about motion would be the claim that motion is in the mind but not the world apart from the mind. In other words, anti-realism about motion would be the claim that the external (mind-independent) world alone cannot ground truths about motion. And Pasnau attributes this claim to Hobbes, also.

However, reductionism about motion does not entail anti-realism about motion. Suppose that bodies are mind-independent, and that motion is identical with a moving body (is nothing over and above that body itself). Consider, for example, a bus. If we speak truly when we say, "the bus is approaching", what grounds this truth? Where is the truth-maker? In the mind or in the world? The truth-maker is the motion of the bus, which is (by hypothesis) identical to the bus itself - a mind-independent body. This 
is a case of reductionism, but not of anti-realism, about motion. For in this case, the mind-independent world alone can ground truths about motion.

Hobbes may believe that motion is not something distinct from or in addition to body and yet still believe, without contradiction, that there is something external to the mind (namely, body itself) that grounds truths about motion. For body itself is not mind-dependent. So even if (as Pasnau seems to claim) Hobbes is a reductionist about motion, this does not prove that he is an anti-realist about motion.

In our work here and in section two, we aimed to show that Hobbes is not, contra Pasnau's interpretation, an anti-realist about "primary qualities" such as magnitude and motion. We hope to have provided very clear and useful data for further reflections and discussion on the topic. ${ }^{12}$

\section{REFERENCES}

Brandt, F. 1928. Thomas Hobbes' Mechanical Conception of Nature. Copenhagen: Levin \& Munksgaard.

Herbert, G. 1987. Hobbes's Phenomenology of Space. Journal of the History of Ideas, 48: 709-717.

Hobbes, T. 1655/ 1981. Part I of De Corpore, chapters 1-6, A.P. Martinich (trans.), New York: Abaris Books.

Hobbes, T. 1651/1994. Leviathan. In Leviathan, with selected variants from the Latin edition of 1668, ed. E. Curley. Indianapolis: Hackett.

Hobbes, T. 1640/1990. The elements of law. In The Elements of Law, Natural and Politic, ed. J. C. A. Gaskin. Oxford: Oxford University Press.

Hobbes, T. 1839. The English Works of Thomas Hobbes of Malmesbury. Ed. W. Molesworth. London: J. Bohn.

Hobbes, T. 1934. Objections to Descartes: Objection II. In The Philosophical Works of Descartes, Vol. II. Objections and Replies, Set III, translated by S. Elizabeth Haldane and G. R. T. Ross. Cambridge: Cambridge University Press.

Jesseph, D. 2006. Hobbesian mechanics. In Oxford Studies in Early Modern Philosophy, eds. D. Garber and S. M. Nadler. pp. 119152. Oxford University Press.

\footnotetext{
12 Thanks to three anonymous referees for helping us improve an earlier draft of this manuscript.
} 
Leijenhorst, C. 2001. The Mechanisation of Aristotelianism: The Late Aristotelian Setting of Thomas Hobbes' Natural Philosophy. Brill.

Pasnau, R. 2011. Metaphysical Themes 1274-1671. Oxford: Oxford University Press.

Slowik, E. 2014. Hobbes and the phantasm of space. Hobbes Studies 27.1: 61-79.

Spragens, T. (Jr.). 1973. The Politics of Motion: The World of Thomas Hobbes. Lexington: The University Press of Kentucky. 